Article

\title{
Evolution of Crop Water Productivity in the Nile Delta over Three Decades (1985-2015)
}

\author{
Samia M. El-Marsafawy ${ }^{1}$, Atef Swelam ${ }^{2,3, *}$ (i) and Ashraf Ghanem ${ }^{4}$ \\ 1 Soils, Water \& Environment Research Institute, Agricultural Research Centre, Giza 12112, Egypt; \\ samiaelmarsafawy797@hotmail.com \\ 2 Agricultural Engineering Department, Faculty of Agriculture, University of Zagazig, Zagazig 44511, Egypt \\ 3 International Centre for Agricultural Research in the Dry Areas (ICARDA), Cairo 2416, Egypt \\ 4 Irrigation and Hydraulics Department, Faculty of Engineering, Cairo University, Giza 12613, Egypt; \\ ashrafghanem@eng.cu.edu.eg \\ * Corresponding: a.swelam@cgiar.org; Tel.: +20-233-367-514
}

Received: 23 May 2018; Accepted: 21 August 2018; Published: 31 August 2018

\begin{abstract}
Estimating crop water productivity (CWP) for spatially variable climatic conditions in Egypt is important for the redistribution of crop planting to optimize production per unit of water consumed. The current paper aims to estimate maximum CWP trends under conditions of the Northern Nile Delta over three decades to choose crops that exhibit a higher productivity per unit of water and positive trends in the CWP. The Kafr El Sheikh Governorate was selected to represent the Northern Nile Delta Region, and mean monthly weather data for the period of 1985 to 2015 were collected to calculate standardized reference evapotranspiration and crop water use for a wide array of crops grown in the region using the CROPWAT8.0 model. The CWP was then calculated by dividing crop yield by seasonal water consumption. The CWP data range from 0.69 to $13.79 \mathrm{~kg} \cdot \mathrm{m}^{-3}$ for winter field crops, 3.40 to $10.69 \mathrm{~kg} \cdot \mathrm{m}^{-3}$ for winter vegetables, 0.29 to $6.04 \mathrm{~kg} \cdot \mathrm{m}^{-3}$ for summer field crops, 2.38 to $7.65 \mathrm{~kg} \cdot \mathrm{m}^{-3}$ for summer vegetables, 1.00 to $5.38 \mathrm{~kg} \cdot \mathrm{m}^{-3}$ for nili season crops (short-season post summer), and 0.66 to $3.35 \mathrm{~kg} \cdot \mathrm{m}^{-3}$ for orchards. The crops with the highest CWP values $\left(\mathrm{kg} \cdot \mathrm{m}^{-3}\right)$ over three decades in descending order are: sugar beet (13.79), potato (w2) (10.69), tomato (w) (10.58), eggplant (w) (10.05), potato (w1) (9.98), cucumber (w) (9.81), and cabbage (w) (9.59). There was an increase in CWP of $41 \%$ from the first to the second and $22 \%$ from the second to the third decade. The CWP increase is attributed to a small decrease in water consumption and to a considerable increase in crop yield. The yield increases are attributed mainly to the planting of higher yielding varieties and/or the application of better agronomic practices.
\end{abstract}

Keywords: CROPWAT8.0; crop yield; evapotranspiration; crop pattern planning; irrigation; climate

\section{Introduction}

In the face of growing water scarcity, declining water quality, and the uncertainties of climate change, improving the efficiency and productivity of crop water use, while simultaneously reducing negative environmental impacts is of utmost importance in responding to the increasing food demand of the growing world population. To this end, irrigated and rain-fed agriculture must adopt more science-based, intensive management solutions (Pasquale et al., 2012) [1]. In arid and semi-arid lands, irrigated agriculture is by far the largest consumer of developed water supply. With a growing population, competing demands between industry and municipal water use and use in agriculture are increasing. Since less water is available for agricultural production, future food security is endangered. Consequently, it is imperative to produce more food with less water by increasing CWP. Several strategies for enhancement of CWP by integrating improved crop varieties and better resource 
management at different levels are suggested by the author of Woolley et al., 2009 [2]. Possible strategies include: (1) increasing the harvest index; (2) improving drought and salinity tolerance; (3) applying deficit irrigation; and (4) adjusting the planting and tillage dates to reduce evaporation and increase infiltration; reusing water, and using spatial analysis to identify areas of maximum production and minimum evapotranspiration (ET). A higher CWP results from either decreasing water usage, increasing production, or some combination of both that narrows the gap between supply and demand. In this study, CWP $\left(\mathrm{kg} \cdot \mathrm{m}^{-3}\right)$ is defined as the ratio of marketable crop yield to evapotranspiration (Zwart and Bastiaanssen, 2004) [3]. Numerous studies have documented CWP for various crops throughout the world. Examples include a CWP evaluation of drip irrigated corn grown in the Bekaa Valley of Lebanon (Karam et al., 2003) [4]. A study to compare regional yield, actual water consumption, and water productivity of cotton lint grown in Arizona and California was presented by Grismer (2002) [5].

In Egypt, as a result of the limited water resources, expansion of agricultural lands, and high population growth, evaluating CWP for different climatic zones is important for the development of agricultural policies and strategies. The Nile Delta presents about $50 \%$ of all agricultural lands of Egypt and is home to about half the Egyptian population. This study investigates the changes in maximum CWP over three decades to identify trends in CWP. The paper ranks the crops by CWP with the aim to provide decision support for deciding which crops perform best in a particular region. The paper presents a methodology as a guide for other regions of Egypt to recommend redistribution of the cropping pattern and crop choices for better production and income. However, the choice of crops also depends on markets and social and economic considerations, which are important and need consideration when using the guidelines in this paper.

\section{Materials and Methods}

\subsection{Study Area}

Kafr El-Sheikh Governorate was selected to represent the conditions in the northern part of the Nile Delta Region. Kafr El Sheikh is located in the Northern Nile Delta, extending between the Rosetta Branch of the Nile in the west and Dakahlia Governorate in the east. It is bordered in the north by the Mediterranean Sea and in the south by Gharbia Governorate.

This region is often seen as a model basin, due to its innovative approaches to manage and allocate water resources sustainably across economic sectors. The selected site represents agriculture and aquaculture ecosystems. Kafr El Sheikh Governorate covers an area of about $3748 \mathrm{~km}^{2}$. El Burullus Lake, which is one of Egypt's major northern lakes and a natural protectorate, occupies about 48,000 ha of the governorate area. With 251,000 ha of agricultural lands, Kafr El Sheikh is one of the leading agricultural governorates in Egypt. Most of the lands in the middle and southern parts of the governorate are covered by Holocene clay deposits, overlying Pleistocene marine deposits, while the northern part is covered predominantly by sandy Pleistocene marine deposits and sand dunes. The governorate ranks first in Egyptian fish production (about 34\% of the total). Kafr El Sheikh has a moderate Mediterranean climate. Mean temperatures range between $13.2{ }^{\circ} \mathrm{C}$ in winter and $26.6{ }^{\circ} \mathrm{C}$ in summer. The annual rainfall varies between about $50 \mathrm{~mm}$ in the south to $200 \mathrm{~mm}$ in the north, with an annual mean of about $97 \mathrm{~mm}$ (EEAA, 2015) [6].

In the Nile Delta, water adequacy is not a major issue at the system level, because water is recycled and reused several times throughout the area with a subsurface drainage system. Thus, reusable drainage water is accessible to farms that experience local temporary water shortage. However, sometimes farmers located at the tail end of canals face water shortage due to operational issues, which are recoverable by using the drainage water. Moreover, farming systems in the Nile Delta are intensifying and diversifying, which puts more pressure on the water delivery supply system. This has increased multiple cropping and double cropping considerably in the Nile Delta. Therefore, improving application efficiency is a major challenge because farmers often use more water than needed, which 
causes about $30 \%$ to $50 \%$ on-farm water loss. However, this is not an absolute water loss at the system level, owing to solutions offered by the water reuse drainage system. The source of water for the study area is from the Nile; there is no shortage year-round and no reduction in water allocation during the growing seasons (summer, nili and winter).

\subsection{Tested Crops}

Egypt has several perennial crops that grow all year where field crops are planted mainly in two or three seasons: winter (October through April), summer (May through September), and sometimes in the nili season (July through October). Ten winter crops (barley, faba bean (green), faba bean (dry), flax, garlic, lentil, lupine, onion, sugar beet, and wheat), eight winter vegetables (cabbage, cucumber, eggplant, pepper, potato (w1), potato (w2), squash, and tomato), six summer crops (cotton, maize, rice, soybean, sugarcane, and sunflower), nine summer vegetables (cabbage, cucumber, eggplant, okra, pepper, potato, squash, tomato, and water melon), two nili crops (maize and tomato), and seven orchard crops (apple, banana, date palm, grapes, mango, orange, and peach) were examined. Note that potato (w1) is sown in September and potato (w2) is sown in November.

\subsection{Estimation of Crop Water Productivity}

According to Kassam and Smith [7], CWP is defined as crop yield divided by water consumptively used for ET. The data on crop yield for winter, summer, nili, and perennial crops were obtained from MALR [8]. The unavailability of yield data for some crops reduces the number of representative years for analysis, but there is sufficient data for this study. There are a few records of crop evapotranspiration $\left(\mathrm{ET}_{\mathrm{c}}\right)$ measurements within the area during the three-decade study period. Consequently, $\mathrm{ET}_{\mathrm{c}}$ calculations from climate data are used to identify the seasonal crop water use. According to the author of Allen et al., 1998 [9], well-watered crop evapotranspiration $\left(\mathrm{ET}_{\mathrm{c}}\right)$ is calculated by multiplying the reference crop evapotranspiration $\left(\mathrm{ET}_{\mathrm{o}}\right)$ by a crop coefficient $\left(\mathrm{K}_{\mathrm{c}}\right)$ :

$$
\mathrm{ET}_{\mathrm{c}}=\mathrm{K}_{\mathrm{c}} \times \mathrm{ET}_{\mathrm{o}}
$$

where $\mathrm{ET}_{\mathrm{c}}$ is in $\mathrm{mm} \mathrm{d}^{-1}, \mathrm{~K}_{\mathrm{c}}$ is the crop coefficient (dimensionless), and $\mathrm{ET}_{\mathrm{o}}$ is the standardized reference evapotranspiration in $\mathrm{mm} \mathrm{d}^{-1}$.

The $\mathrm{ET}_{\mathrm{o}}\left(\mathrm{mm} \mathrm{d}^{-1}\right)$ was calculated by the Food and Agriculture Organization of the United Nations (FAO) Penman-Monteith method using the decision support software CROPWAT 8.0 developed by FAO. The standardized $\mathrm{ET}_{\mathrm{O}}$ equation is:

$$
\mathrm{ET}_{\mathrm{o}}=\frac{0.408 \Delta\left(R_{n}-G\right)+\gamma \frac{900}{T+273} u_{2}\left(e_{s}-e_{a}\right)}{\Delta+\gamma\left(1+0.34 u_{2}\right)}
$$

where $R_{n}\left(\mathrm{MJ} \mathrm{m}^{-2} \mathrm{~d}^{-1}\right)$ is the net radiation, $G$ is the soil heat flux density ( $\left.\mathrm{MJ} \mathrm{m}^{-2} \mathrm{~d}^{-1}\right)$, T is the mean daily air temperature at 1.5 to $2 \mathrm{~m}$ height $\left({ }^{\circ} \mathrm{C}\right), u_{2}$ is the mean daily wind speed at $2 \mathrm{~m}$ height $\left(\mathrm{m} \mathrm{s}^{-1}\right)$, $e_{S}$ is the saturation vapour pressure $(\mathrm{kPa}), e_{a}$ is the actual vapour pressure $(\mathrm{kPa}), e_{s}-e_{a}$ is the saturation vapour pressure deficit $(\mathrm{kPa}), \Delta$ is the slope of the vapour pressure curve $\left(\mathrm{kPa}^{\circ} \mathrm{C}^{-1}\right)$ at the mean daily temperature $\left({ }^{\circ} \mathrm{C}\right)$, and $\gamma$ is the psychrometric constant $\left(\mathrm{kPa}^{\circ} \mathrm{C}^{-1}\right)$.

The agricultural lands in the study area are fully irrigated with flood irrigation having a typical distribution uniformity DU $=0.60$. The crops are grown on heavy clay soil and there is ample year-round irrigation water application; thus, it is assumed that there is no water stress and measured actual $\left(\mathrm{ET}_{\mathrm{act}}\right)$ and well-watered $\left(\mathrm{ET}_{\mathrm{c}}\right)$ are equal for recent measurements in the study area. The area is served by an agricultural drainage system, which consists of subsurface field drains discharging into a dendritic open drain system. The open drains are used by farmers for supplemental irrigation in case of temporary water shortage in the irrigation canals. Comparisons were made between observed water consumption and $\mathrm{ET}_{\mathrm{c}}$ estimated for wheat grown in Egypt using the same $\mathrm{K}_{\mathrm{c}}$ values; however, $\mathrm{ET}_{\mathrm{o}}$ using the modified Penman, Penman-Monteith, and Doorenbos-Pruitt equations is 
reported by the authors of El-Marsafawy et al., 1998 [10]. They found that the ratio between the actual water consumption and $\mathrm{ET}_{\mathrm{C}}$ estimated by the three formulas were 1.05, 1.02, and 0.95, respectively. Similar results were obtained by the authors of Mohamed et al., 2004; El-Samanody et al., 2004; El-Marsafawy et al., 1998; Rayan et al., 2000 [11-14] for other crops. The results indicate that the Penman Monteith method provides the closest match between $\mathrm{ET}_{\mathrm{act}}$ and $\mathrm{ET}_{\mathrm{C}}$. Therefore, the calculated values of $\mathrm{ET}_{\mathrm{C}}$ are used in this research to determine crop water consumption and CWP.

Archived daily meteorological data from the weather station located in the Agricultural Research Center station in Sakha, Kafr El Sheikh Governorate (Elevation: 20 m; Latitude: $31.07^{\circ}$ N, Longitude: $30.57^{\circ} \mathrm{E}$ ), which is representative of the Northern Nile Delta Region, are used to compute monthly $\mathrm{ET}_{\mathrm{o}}$ data for each year of the three decades. The monthly $\mathrm{ET}_{\mathrm{C}}$ data are computed with Equations (1) and (2) using monthly $\mathrm{ET}_{\mathrm{o}}$ estimated from the weather data and appropriate crop coefficients from CROPWAT 8.0. For each growing season, the CWP was computed from the observed yield and the cumulative seasonal $\mathrm{ET}_{\mathrm{c}}$, assuming well-watered conditions. The $\mathrm{CWP}$ is computed as:

$$
\mathrm{CWP}=\frac{\mathrm{YLD}}{\mathrm{CET}_{\mathrm{C}}}
$$

where the crop yield (YLD, $\mathrm{kg} \cdot \mathrm{m}^{-2}$ ) and the seasonal cumulative $\mathrm{ET}_{\mathrm{c}}\left(\mathrm{CET}_{\mathrm{c}}, \mathrm{m}^{3} \mathrm{~m}^{-2}\right.$ ) are inputs. Therefore, since no water stress is assumed in these data, the CWP values represent the maximum crop water productivity values by season, and the analysis in this paper shows how these peak values change over the study period due to $\mathrm{CET}_{\mathrm{c}}$ differences. For future studies on how water stress affects CWP, results from this study will be useful to identify maximum yields from seasonal $\mathrm{ET}_{\mathrm{C}}$.

To simplify the presentation of the CWP results, the values are determined by crop and season for all crops and years, and the mean CWPs by decade are calculated to investigate trends in CWPs over time. The objective is to present data that help the decision-making process that identifies what crops to grow within the study region and whether or not the maximum CWPs increase or decrease with time.

\section{Results and Discussion}

\subsection{Winter Field and Vegetable Crops}

Mean CWP by decade for the winter field crops barley, faba bean (green), faba bean (dry), flax, garlic, lentil, lupine, onion, sugar beet and wheat are plotted in Figure 1. The trend of increasing CWP for several crops with time is clear, with a few exceptions. The CWP trends are near unit for faba bean (dry), lentil and lupine and slightly increased for wheat and barley. Moderate to high increases were observed for faba bean (green), flax, garlic, and pepper. The onion, sugarbeet, cabbage, cucumber $(w)$, eggplant (w), potato (w1), potato (w2), squash, and tomato showed high CWP values, which indicate good water productivity in the region. Sugarbeet, cabbage (w), cucumber (w), eggplant (w), potato (w1), potato (w2) and tomato showed the biggest trends toward high CWP, especially in the last two decades. Cucumber showed a large increase in CWP from the first to second, with a drop in the third decade. However, the CWP in the third decade was still considerably higher than the first. Water productivity trends show that some crops increase productivity much faster than others. The fluctuation in results may be due to differences in weather conditions, genotypes, agricultural practices, and disease, among others.

Average CWP for winter vegetables over the study period reached 9.59, 9.81, 10.05, 3.40, 9.98, $10.69,6.51$ and $10.58 \mathrm{~kg} \cdot \mathrm{m}^{-3}$ for cabbage, cucumber, eggplant, pepper, potato (w1), potato (w2), squash and tomato, respectively. Data presented in the graphs clearly show an increase in CWP of cabbage, eggplant, pepper, squash and tomato in the third decade. Percentage increase for the respective crops was 35\%, 40\%, 97\%, 19\%, and 210\% compared to the first decade and $17 \%, 59 \%, 62 \%, 21 \%$, and $72 \%$ compared to the second decade. 
With regard to potato (w1, sown in September) and potato (w2, sown in November), as stated above, potato (w1) was not grown in the first decade and potato (w2) was not grown in the third decade. The results indicate that CWP of the third decade surpassed that of the second decade for potato (w1) and the second decade surpassed the 1st decade for potato (w2). As for cucumber, the percent change in CWP of the third decade was $+81 \%$ compared with the first decade and $-40 \%$ compared with the second decade.

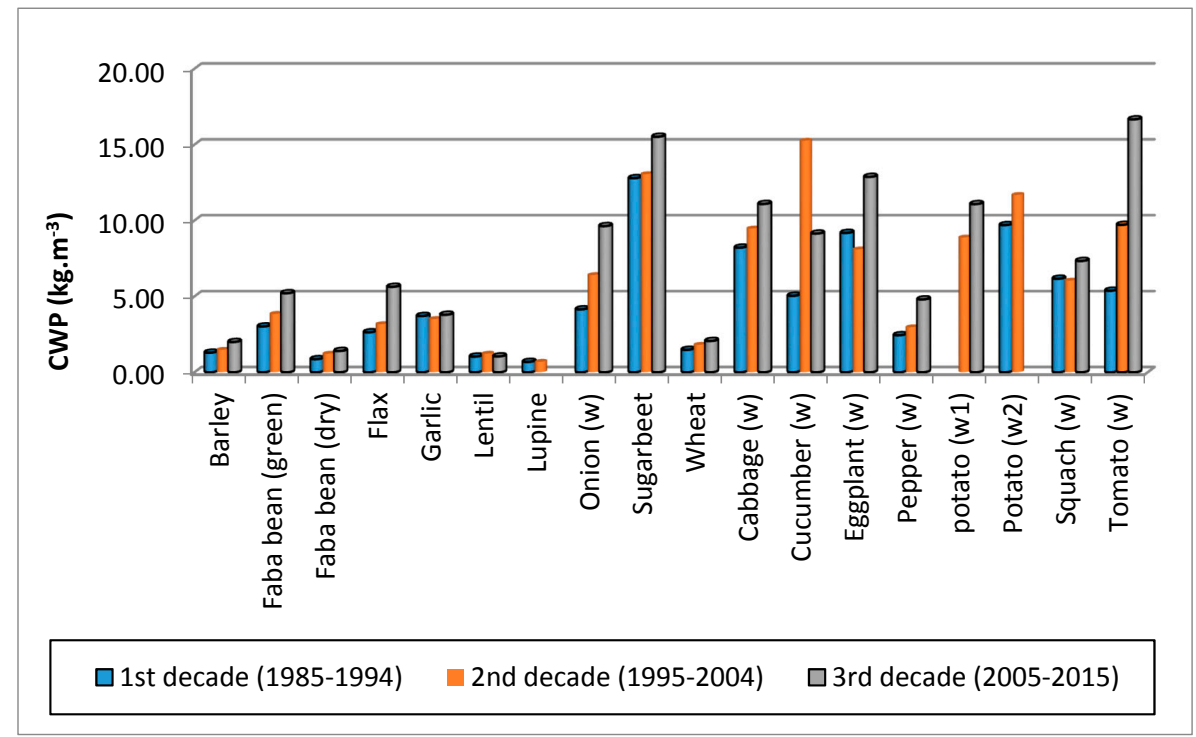

Figure 1. Crop water productivity (CWP) for winter field and vegetable crops over three decades under Northern Nile Delta conditions.

The water utilization efficiency $\left(\mathrm{kg} \cdot \mathrm{m}^{-3}\right)$ reported by the author of Doorenbos and Kassam, 1986 [15] were for cabbage (12-20), dry bean (0.3-0.6), onion (8-10), pepper (1.5-3.0), potato (4-7), sugarbeet (6-9), tomato (10-12), and wheat (0.8-1.0). In comparison, the third decade values from this study were lower for lentil and cucumber; higher for barley, faba bean (green), faba bean (dry), flax, garlic, onion, wheat, cabbage, pepper, potato and squash; and much higher for sugarbeet, eggplant and tomato. Therefore, the North Nile Delta Region is probably a better place to grow potato, sugarbeet, and tomato than the typical region represented in FAO 33. The author of Rayan et al., 1999 [16] indicated that the CWP observed for wheat crop in the Shandaweel region (Upper Egypt) ranged between 0.43 to $1.44 \mathrm{~kg} \cdot \mathrm{m}^{-3}$ and between 0.83 to $1.70 \mathrm{~kg} \cdot \mathrm{m}^{-3}$ in the Giza Region of Middle Egypt (El-Marsafawy, 2000) [17]. This is lower than the CWP (close to $2.0 \mathrm{~kg} \cdot \mathrm{m}^{-3}$ ) observed in the third decade of this study. This implies that it is probably better to grow wheat in the Northern Nile Delta Region than the regions further south.

\subsection{Summer Field and Vegetable Crops}

Values of CWP for summer field crops varied in the past three decades. CWP values were quite low and showed little or no increasing trend for cotton, soybean, and sunflower (Figure 2). The CWP was a bit higher for maize, rice and peppers with an increasing trend. Sugarcane, cabbage (s), cucumber (s), eggplant (s), okra, and squash showed higher CWP and bigger trends. The highest CWP and biggest trends were exhibited by potato (s), tomato (s) and watermelon. Based on these observations, potato (s), tomato (s), and watermelon have the highest CWP as well as the biggest trend towards higher CWP. In comparison with the results in Figure 1, tomatoes have higher CWP in the winter than the summer. The potatoes also have higher CWP in the winter (Figure 1) than the summer (Figure 2). It seems likely that the reduced CWP in summer is due to higher ET rates and possible effects of some heat stress on production. 


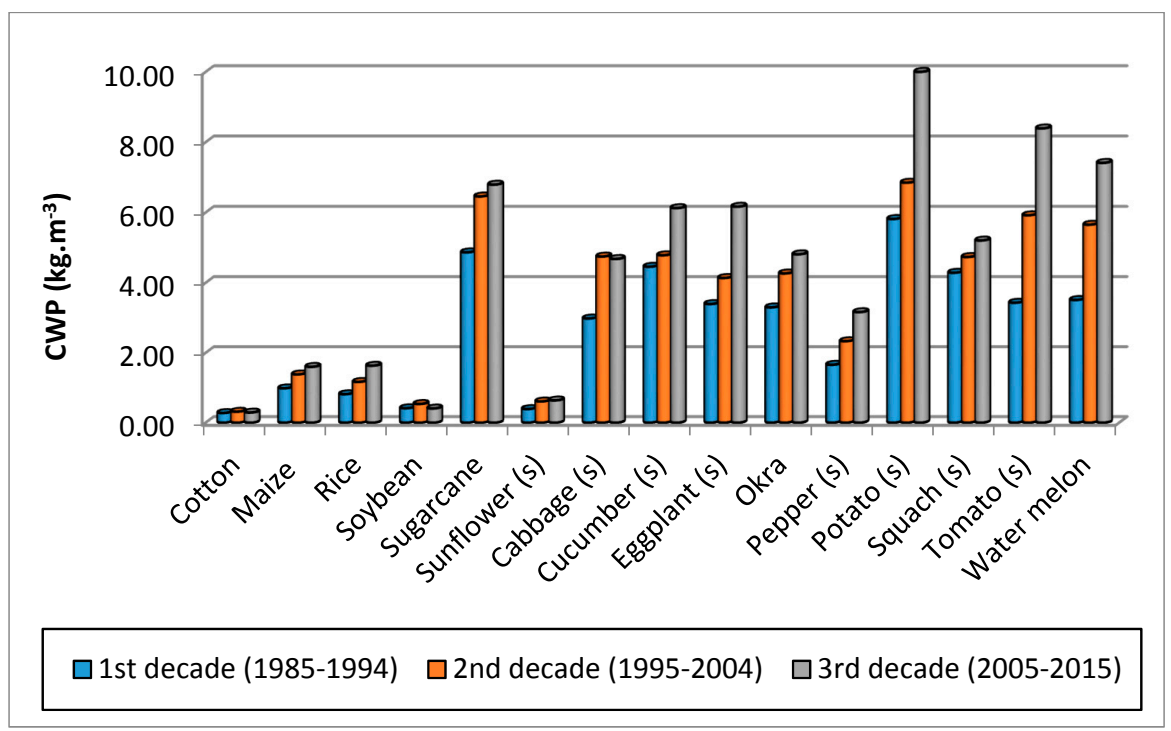

Figure 2. Crop water productivity (CWP) for summer field and vegetable crops over three decades under Northern Nile Delta conditions.

\subsection{Nili Crops}

Mean CWP over the study period amounted to 1.00 and $5.38 \mathrm{~kg} \cdot \mathrm{m}^{-3}$ for maize and tomato, respectively. CWP was somewhat lower for maize grown during the nili period (Figure 3) than during summer (Figure 2), and the CWP trend for maize was near $1.0 \mathrm{~kg} \cdot \mathrm{m}^{-3}$ per decade. Tomato CWP values were similar in the nili and summer periods, but both were lower than the winter period (Figure 1). All three periods showed increasing CWP trends over the three decades, indicating improvements in production and/or reductions in water consumption.

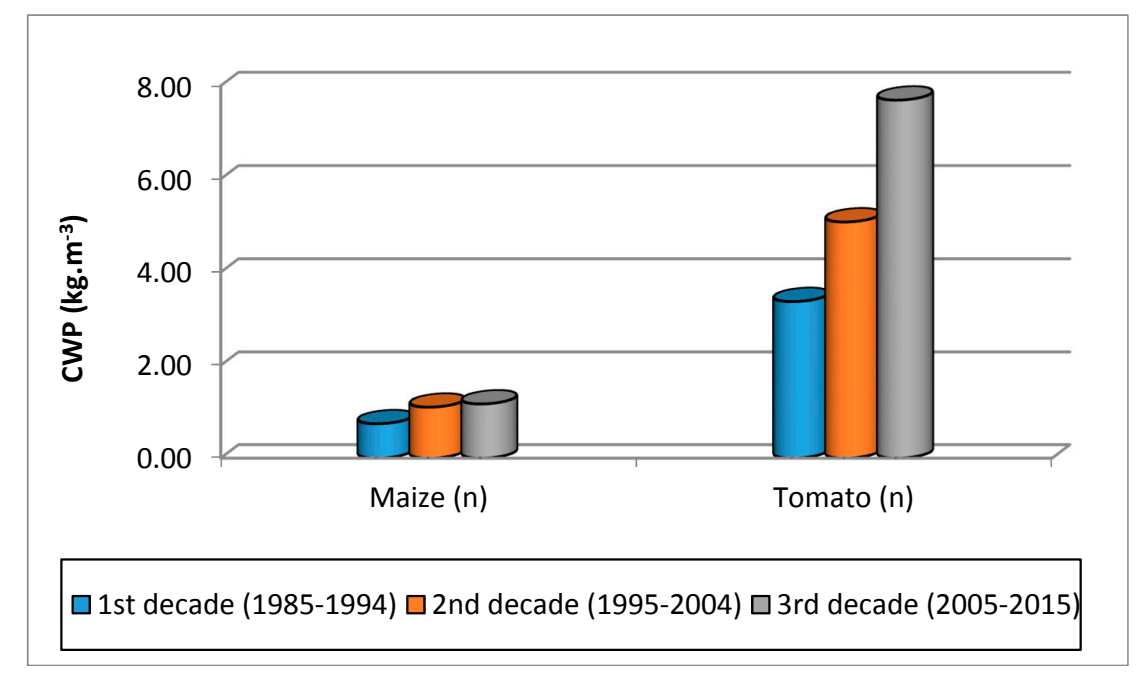

Figure 3. Crop water productivity (CWP) for nili crops over three decades under Northern Nile Delta conditions.

\subsection{Orchard Trees}

Mean CWP for orchard trees over three decades reached 2.16, 3.35, 3.32, 3.07, 0.66, 2.62, $1.98 \mathrm{~kg} \cdot \mathrm{m}^{-3}$ for apple, banana, date palm, grapes, mango, orange, and peach, respectively. The CWP values (Figure 4) were generally lower than that of the high CWP field and vegetable crops 
sugar beet, cabbage, cucumber, eggplant, potato, and tomato (Figures 1-3), which implies that they are not the best crops to grow in terms of water productivity. However, in economic terms, they are often highly productive. This aspect will receive more attention in future research. Of the orchard crops shown in Figure 4, mango is clearly less water productive than the other trees. In addition, there are obvious CWP improvements for all the crops, with bananas, dates, and grapes exhibiting the biggest trends.

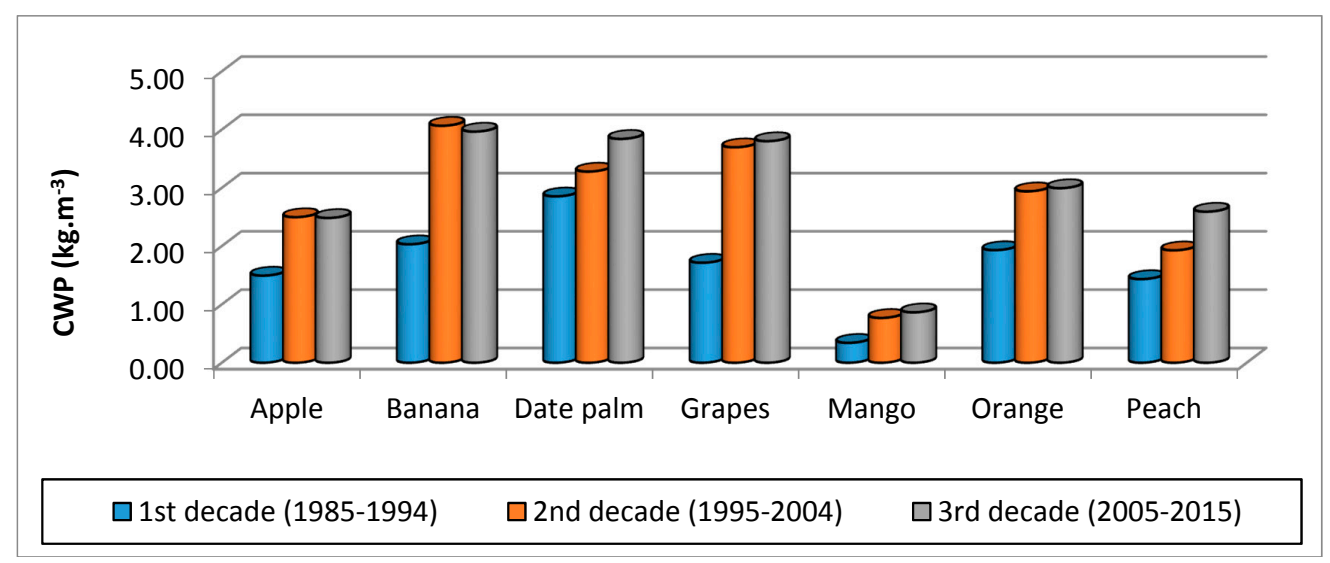

Figure 4. Crop water productivity (CWP) for orchards over three decades under North Nile Delta conditions.

As described, Egyptian agriculture has demonstrated increasing CWP during the recent decades. For most crops, the improvements are mainly due to the application of good agricultural practices that help to maximize the productivity per unit of water consumed. These efforts help to maintain available resources and achieve sustainability. A plot of the mean CWP for all crops under study is shown in Figure 5. The crops with the highest CWP values $\left(\mathrm{kg} \cdot \mathrm{m}^{-3}\right)$ under North Nile Delta conditions include: sugar beet (13.79), potato (w2) (10.69), tomato (w) (10.58), eggplant (w) (10.05), potato (w1) (9.98), cucumber (w) (9.91), and cabbage (w) (9.59). On the other hand, crops with the lowest mean CWP $\left(\mathrm{kg} \cdot \mathrm{m}^{-3}\right)$ are: cotton $(0.29)$, soybean $(0.45)$, sunflower $(0.54)$, lupine $(0.69)$, and mango $(0.72)$.

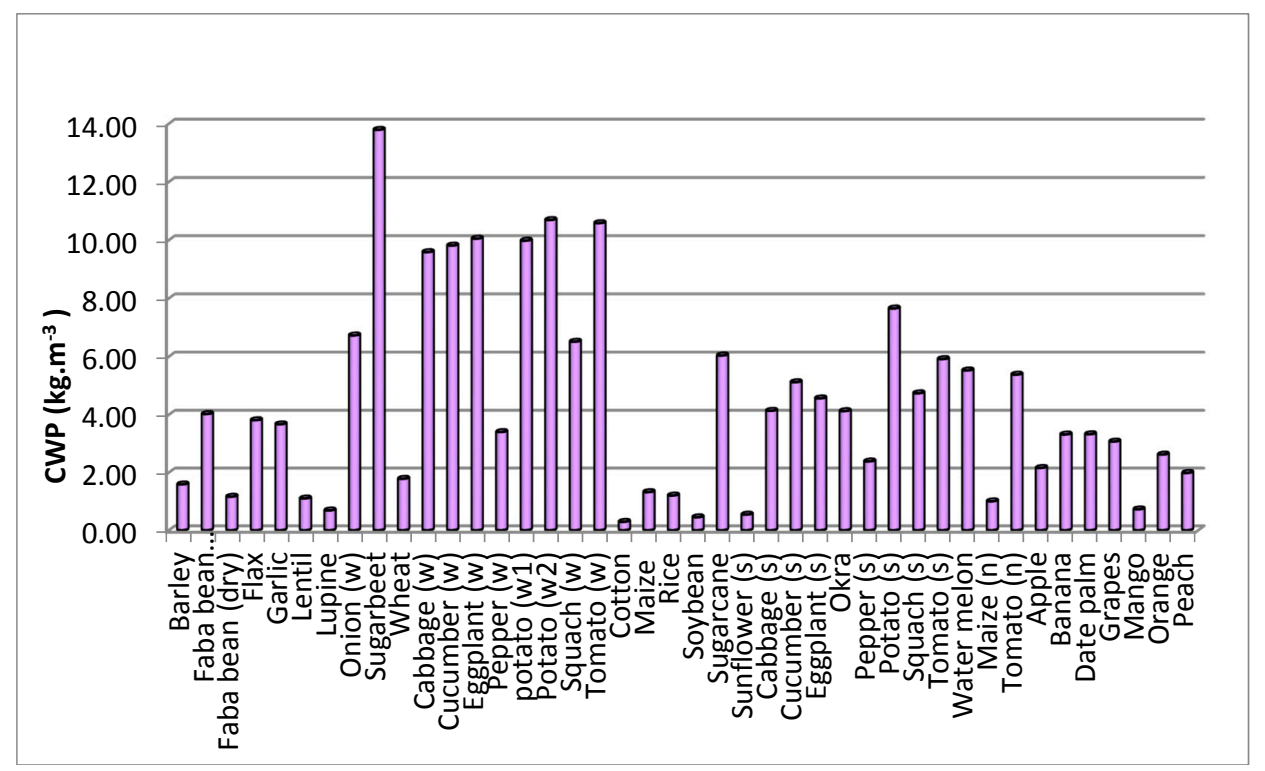

Figure 5. Average crop water productivity (CWP) for Egyptian crops grown in the Northern Nile Delta Region over three decades (av. 1985-2015). Note: $\mathrm{w}=$ winter season; s = summer season; $\mathrm{n}=$ nili season. 
The CWP percentage change trends from decade 1 to 3 are shown in Figure 6 and from decade 2 to 3 in Figure 7.

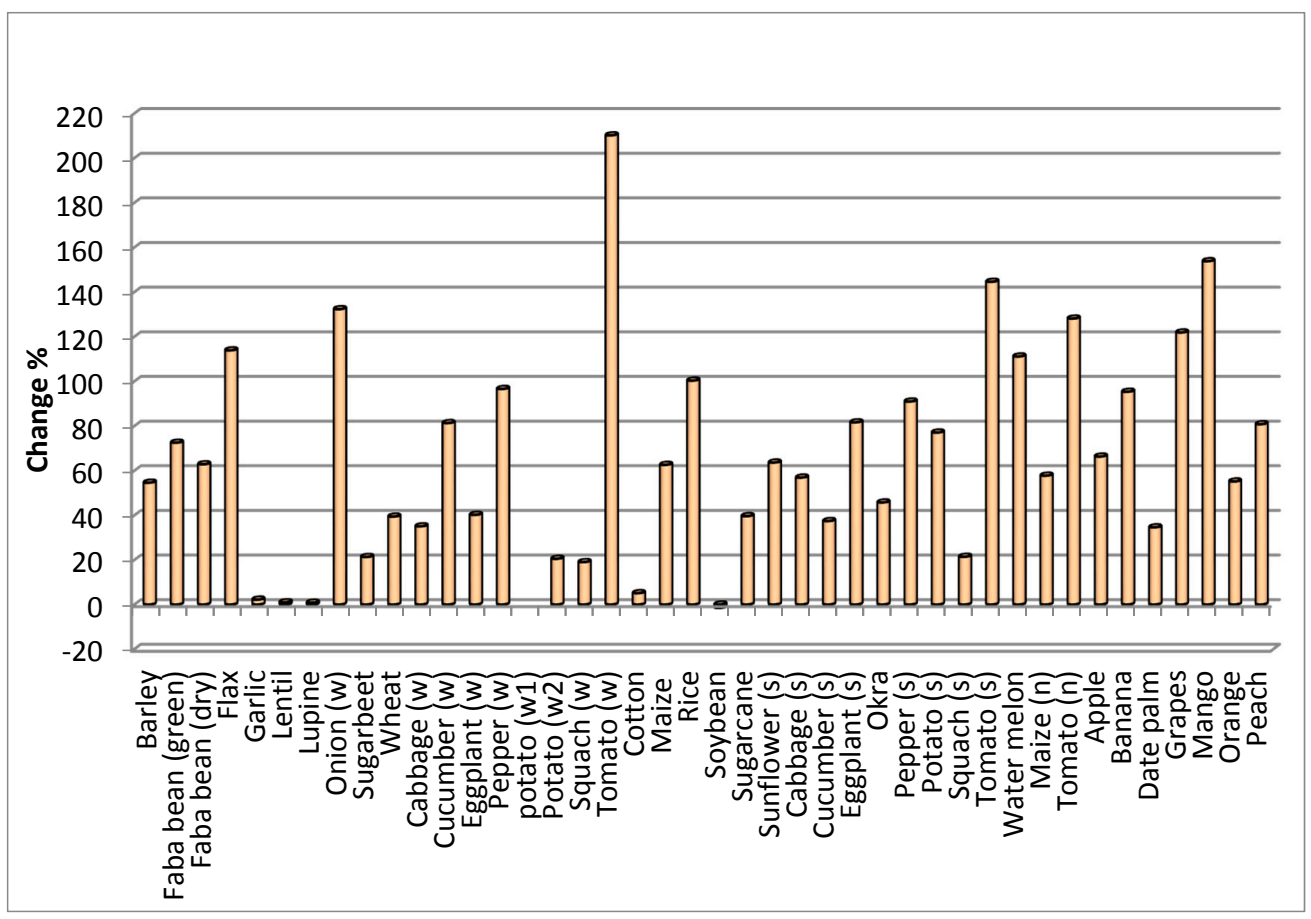

Figure 6. Percent change in CWP for crops grown in the Northern Nile Delta Region in the third decade (2005-2015), compared to the first decade (1985-1994).

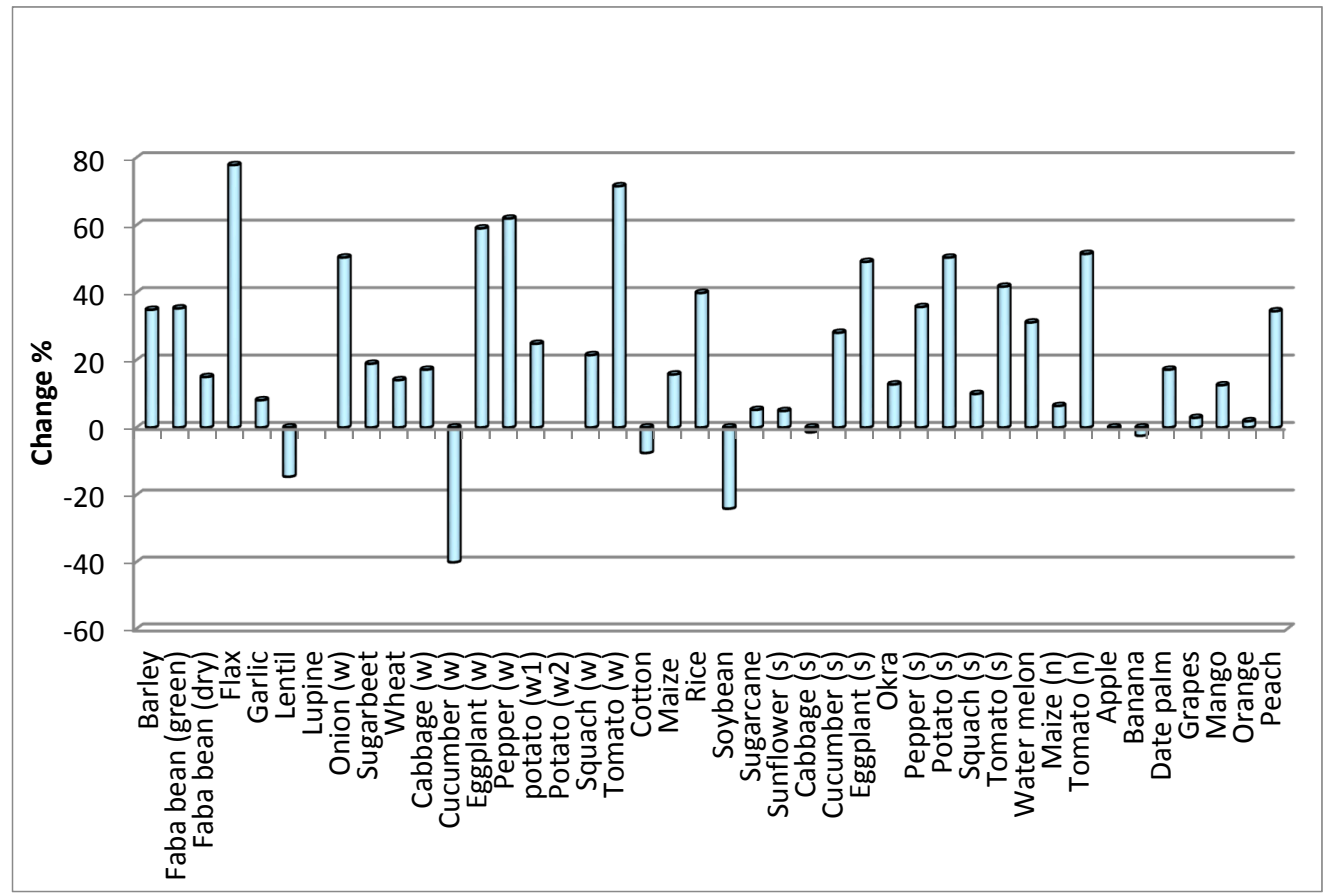

Figure 7. Percent change in CWP for crops grown in the Northern Nile Delta Region in the third decade (2005-2015), compared to the second decade (1995-2004). Note: The absence of some crops in the graph indicates the absence of crop cultivation during that decade. 


\section{Analysis of Results}

An increase in CWP was observed for most crops during the study period. Mean CWP increase for all crops amounted to $41 \%$ from the first to the second decade and $22 \%$ from the second to the third. To examine the reasons behind the increase in CWP, a closer look at the trends of crop yield and water consumption over the study period is needed. Figure 8 presents values of crop yield (ton ha ${ }^{-1}$ ) for crops under consideration in the study, and an increasing yield trend is apparent. The mean increase for all crops was $41 \%$ from the first to the second decade and $22 \%$ from the second to the third. The trends are likely related to the utilization of higher yield cultivars and/or an improvement of agronomic practices. Figure 9 shows that the crop water consumption, represented by $\mathrm{ET}_{\mathrm{c}}$, is declining with time. It is noted that the $\mathrm{ET}_{\mathrm{O}}$ decreased by $3 \%$ from the first to second decade and by $6 \%$ from the second to the third. The $\mathrm{ET}_{\mathrm{o}}$ changed due to climatic factors and not due to agronomic practices. The same $\mathrm{K}_{\mathrm{c}}$ values were used in CROPWAT 8.0 for all of the years; thus, our estimates of $\mathrm{ET}_{\mathrm{C}}$ also decreased by $3 \%$ and $6 \%$ over time. In the third decade, new agronomic practices that reduce ET were widely adopted in Egypt. These practices are discussed below (Swelam, 2016; Alwang et al., 2018; Molden et al., 2010; Ghazouani et al., 2015; Lal and Stewart, 2012; Swelam et al., 2015) [18-23]. While they are widely adopted and can explain some additional increases in CWP due to decreases in ET, the main reason for the increases in CWP are clearly due to better production from using higher yielding crops and better crop and water management. Since the $\mathrm{K}_{\mathrm{c}}$ values were kept constant over the three decades (except for rice, whose variety has changed from long to short duration) the reduction in water consumption must be related to changes in climatic conditions in the study area. The reasons behind this trend are under investigation and shall be the subject of another publication.

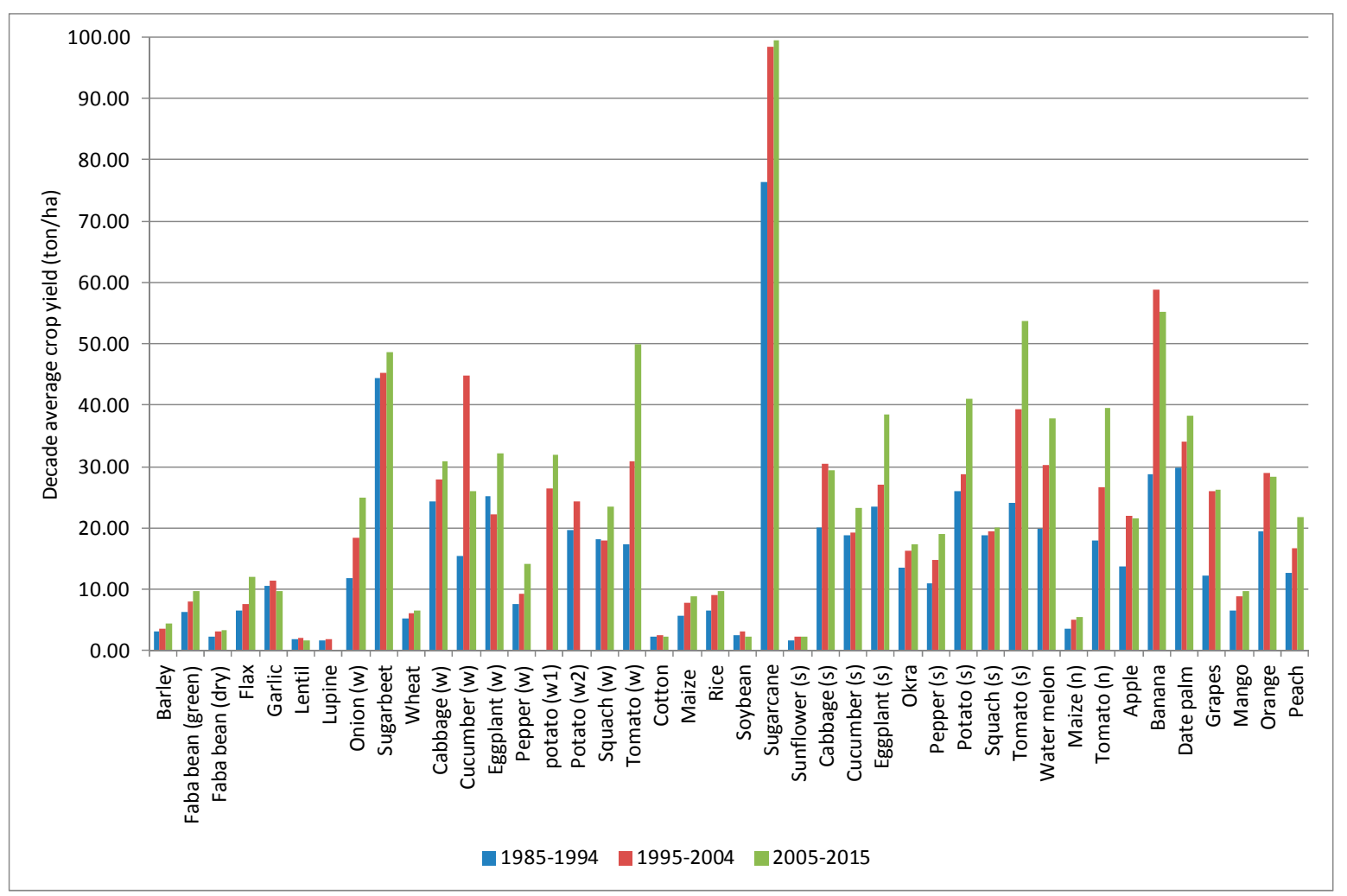

Figure 8. Evolution of crop yield over three decades. 


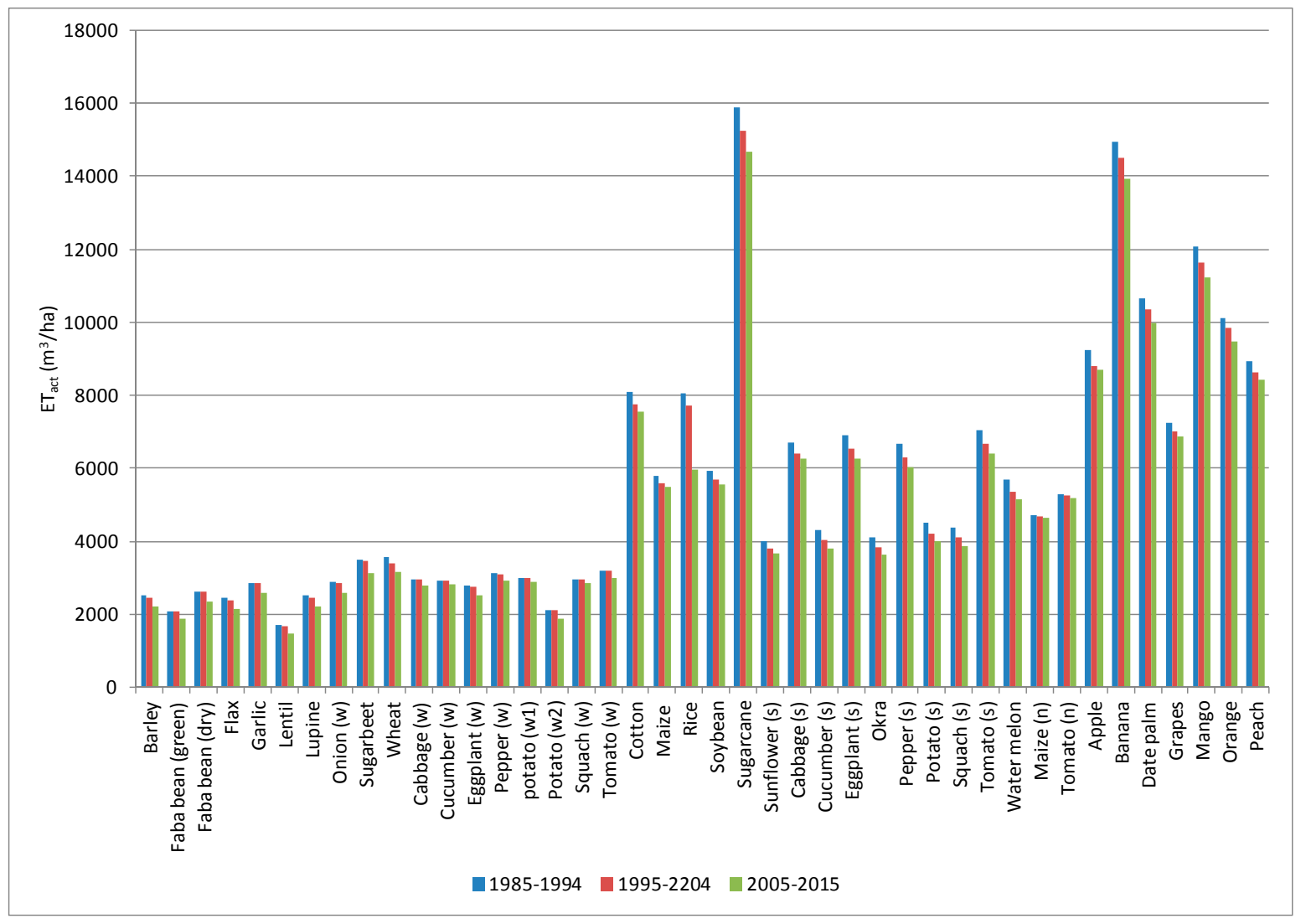

Figure 9. Variation of $\mathrm{ET}_{\text {act }}$ over three decades.

The observed CWP increases are related to a decrease in crop water consumption to some extent and to an increase of crop yield to a larger extent. The increase in CWP is also partly due to better agronomic practices. Many studies and investigations carried out on different crops in different climatic zones in Egypt have shown that using good agricultural and irrigation practices increases crop productivity and saves irrigation water. For example, recent studies showed that using raised beds rather than basin irrigation increased the yield of wheat by $25 \%$ and it reduced applied water by $25 \%$, mainly due to reduction in soil evaporation (Swelam, 2016) [18]. The raised bed system saves labor, time, water and energy costs. The raised bed system increases farm yield by $30 \%$ while reducing production costs by $25 \%$, compared to traditional farming practices. According to the authors of Alwang et al., 2018; Molden et al., 2010; Ghazouani et al., 2015; Lal and Stewart, 2012; Swelam et al., 2015 [19-23], in Egypt, the usage of raised beds has improved surface irrigation efficiency and crop productivity. Using raised beds at a width of $130 \mathrm{~cm}$ with $180 \mathrm{~kg} \mathrm{~N} \mathrm{ha}^{-1}$ led to the highest wheat grain yield. Thus, in dry areas, where water resources are often limited and nutrient uptake and efficiencies are low, the use of a raised bed system with optimal nitrogen fertilizer level provides a distinct advantage.

In Egypt, land levelling is practiced on a large scale by the government and/or private sector. A good example involves sugarcane fields, where the government is subsidizing laser levelling by about $50 \%$ of its cost to improve water productivity and reduce applied water. Another example is in rice cultivation, where levelling is done in flooded fields using a wooden beam and animal traction. This minimizes percolation through the soil profile. According to the author of Allam et al., 2005 [24], the main objectives of land levelling are to achieve better water distribution uniformity and increased crop production as well as minimize water losses through reducing run-off. Thus, about $31 \%$ of the applied water is saved by using laser land leveling in Egypt. 


\section{Conclusions}

In view of the growing water scarcity, declining water quality, and the uncertainties of climate change, improving irrigation efficiency and water productivity, while simultaneously reducing negative environmental impacts is of utmost importance in responding to the increasing food demand of the growing world population. To this end, irrigated agriculture must adopt more knowledge-intensive management solutions. In the current study, crop water productivity (CWP) trends were calculated over three decades, with a focus on the productivity trend of the third decade relative to the first and second decades. The study also identifies crops with high and low CWP under Northern Nile Delta climate conditions.

The CWP increased for most crops under investigation in the region. Crops that achieved the highest increase in mean decadal CWP from the first to the third decade include winter tomato $(210 \%)$, mango $(154 \%)$, summer tomato $(145 \%)$, winter onion $(132 \%)$, nili tomato $(128 \%)$, grapes $(122 \%)$ and flax $(114 \%)$. The analysis showed that most of the increase in CWP is related to increase in crop yield, which increased by $41 \%$ for all crops from the first to the second decade and by $22 \%$ from the second to the third decade. The increase is mainly attributed to the application of better agronomic practices and/or to the utilization of higher yielding varieties. A small decline in overall crop water consumption was observed, i.e., a mean decrease of $3 \%$ from the first to the second and $6 \%$ from the second to the third decade. The reduction in water consumption is likely related to changes in climatic conditions within the study area. In descending order, the crops with the highest CWP values $\left(\mathrm{kg} / \mathrm{m}^{3}\right)$ over three decades were sugar beet, potato (w2), tomato (w), eggplant (w), potato (w1), cucumber (w), and cabbage $(\mathrm{w})$.

This study emphasizes biophysical water productivity rather than policy and economics. Biophysical water productivity is insufficient as a standalone indicator for crop selection. Thus, economic and social comparison is needed for policy support. The objective of this work is to determine what crops have the highest water productivity per unit of water consumed in the Northern Nile Delta Region of Egypt. The results of the study are useful for comparison with other agricultural regions having different climatic conditions to determine which region has the highest water productivity for a particular crop.

Author Contributions: Conceptualization, A.S. and S.M.E.-M.; Methodology, A.S. and S.M.E.-M.; Software and validation, S.M.E.-M., A.S. and A.G.; Formal Analysis, A.S. and S.M.E.-M.; Investigation, A.G.; Resources, A.S.; Data Curation, S.M.E.-M.; Writing-Original Draft Preparation, S.M.E.-M. and A.S.; Writing-Review \& Editing, A.G.; Visualization, A.S. and A.G.; Supervision, A.S.; Project Administration, A.S.; Funding Acquisition, A.S.

Funding: This research was funded by the Arab fund for Economic and Social Development (AFESD) through the Research Collaboration Agreement between The Agricultural Research Center of the Egyptian Ministry of Agriculture and Land Reclamation (ARC) and the International Centre for Agricultural Research in the Dry Areas (ICARDA) under the title, "Sustainability and Operation of the Regional Research Centers in a Number of Arab Countries".

Acknowledgments: The Authors would like to thank Richard Snyder, Biometeorologist at University of California, Davis and Usman Awan, Groundwater specialist at ICARDA for their technical support and review this paper during the writing and preparation processes.

Conflicts of Interest: Declare conflicts of interest or state.

\section{References}

1. Pasquale, S.; Theodore, C.; Hsiao, E.F.; Dirk, R. FAO Irrigation and Drainage Paper 66, Crop Yield Response to Water; Food and Agriculture Organization of the United Nations: Rome, Italy, 2012.

2. Woolley, J.; Cook, S.E.; Molden, D.; Harrington, L. Water, food and development: The cgiar challenge program on water and food. Water Int. 2009, 34, 4-12. [CrossRef]

3. Zwart, S.; Bastiaanssen, W. Review of measured crop water productivity values for irrigated wheat, rice, cotton and maize. Agric. Water Manag. 2004, 69, 115-133. [CrossRef]

4. Karam, F.; Breidy, J.; Stephan, C.; Rouphael, J. Evapotranspiration, yield and water use efficiency of drip irrigated corn in the Bekaa Valley of Lebanon. Agric. Water Manag. 2003, 63, 125-137. [CrossRef] 
5. Grismer, M.E. Regional cotton lint yield, ETc and water value in Arizona and California. Agric. Water Manag. 2002, 54, 227-242. [CrossRef]

6. Egyptian Environmental Affairs Agency (EEAA). The Environmental Profile of Kafr El Sheikh; EEAA: Cairo, Egypt, 2015. (In Arabic)

7. Kassam, A.; Smith, M. FAO methodologies on crop water use and crop water productivity. In Proceedings of the Expert Meeting on Crop Water Productivity, Rome, Italy, 3-5 December 2001.

8. Ministry of Agriculture and Land Reclamation (MALR). Economic Affairs Sector-Bulletin of Important Indicators of the Agricultural Statistics; Volumes No. 1986; MALR: Cairo, Egypt, 2016.

9. Allen, R.G.; Pereira, L.S.; Raes, D.; Smith, M. Crop Evapotranspiration-Guidelines for computing crop water requirements-FAO Irrigation and drainage paper 56. Fao Rome 1998, 300, D05109.

10. El-Marsafawy, S.M.; Ali, M.A.; Salib, A.Y.; Eid, H.M. Effect of different sowing dates on some wheat varieties yield and their water relations. In Proceedings of the Third Conference of Meteorology \& Sustainable Development, Cairo, Egypt, 15-17 February 1998.

11. Mohamed, K.A.; El Lithy, R.E.; Samia, M.E. Effect of withholding irrigation at different growth stages on productivity of some soybean varieties. Ann. Agric. Sci. Moshtohor 2004, 42, 1441-1456.

12. El-Samanody, M.K.M.; Awad, M.A.; El-Marsafawy, S.M. Scheduling irrigation of canola under nitrogen sources in Middle Egypt. Misr J. Agric. Eng. 2004, 21, 165-188.

13. El-Marsafawy, S.M.; Salib, A.Y.; Ali, M.A.; Eid, H.M. Row width and nitrogen levels impacts on water relations, growth and yield of maize crop. In Proceedings of the Third Conference of Meteorology \& Sustainable Development, Cairo, Egypt, 15-17 February 1998.

14. Rayan, A.A.; Mohamed, K.A.; Khalil, F.A.; El-Marsafawy, S.M. Scheduling irrigation of cotton crop under different nitrogen fertilizer levels in Upper Egypt. In Proceedings of the 5th Conference Meteorology \& Sustainable Development, Cairo, Egypt, 22-24 February 2000.

15. Doorenbos, J.; Kassam, A. Yield Response to Water. FAO Irrigation; Drainage Paper No. 33; Pergamon Press: Oxford, UK, 1986.

16. Rayan, A.A.; El-Marsafawy, S.M.; Mohamed, K.A. Response of some wheat varieties to different sowing dates and irrigation regimes in Upper Egypt. In Proceedings of the 3rd Conference of On-Farm Irrigation and Agroclimatology, Cairo, Egypt, 25-27 January 1999.

17. El-Marsafawy, S.M. Scheduling irrigation of wheat crop under different phosphorus fertilizer application times in Middle Egypt. In Proceedings of the 5th Conference of Meteorology \& Sustainable Development, Cairo, Egypt, 22-24 February 2000.

18. Swelam, A. Science Impact: Raised-Bed Planting in Egypt: An Affordable Technology to Rationalize Water Use and Enhance Water Productivity. Available online: http:/ /www.icarda.org/sites/default/files/u158/ Science\%20Impact\%20Raised-Bed_final.pdf (accessed on 6 February 2016).

19. Alwang, J.; Sabry, S.; Shideed, K.; Swelam, A.; Halila, H. Economic and food security benefits associated with raised-bed wheat production in Egypt. Food Secur. 2018, 10, 589-600. [CrossRef]

20. Molden, D.; Oweis, T.; Steduto, P.; Bindraban, P.; Hanjra, M.A.; Kijne, J. Improving agricultural water productivity: Between optimism and caution. Agric. Water Manag. 2010, 97, 528-535. [CrossRef]

21. Ghazouani, W.; Molle, F.; Swelam, A.; Rap, E.; Abdo, A. Understanding Farmers' Adaptation to Water Scarcity: A Case Study from the Western Nile Delta, Egypt; IWMI: Colombo, Sri Lanka, 2015.

22. Lal, R.; Stewart, B.A. Soil Water and Agronomic Productivity; CRC Press: New York, NY, USA, 2012.

23. Swelam, A.A.; Hassan, M.A.; Osman, E.A.M. Effect of raised bed width and nitrogen fertilizer level on productivity and nutritional status of bread wheat. Egypt J. Appl. Sci. 2015, 30, 223-234.

24. Allam, M.N.; El Gamal, F.; Hesham, M. Irrigation systems performance in Egypt. Irrig. Syst. Perform. Options Méditerr. Sér. B Etudes Rech. 2005, 52, 85-98.

(C) 2018 by the authors. Licensee MDPI, Basel, Switzerland. This article is an open access article distributed under the terms and conditions of the Creative Commons Attribution (CC BY) license (http:/ / creativecommons.org/licenses/by/4.0/). 